\title{
THE STUDY OF FREE COUMARINS IN THE PLANT RAW MATERIAL OF MEDICAGO FALCATA L. SUBSP. ROMANICA (PRODAN) O. SCHWARZ \& KLINK
}

\author{
O.V.Grechana \\ Zaporizhzhia State Medical University
}

Key words: Medicago falcata L. subsp. romanica (Prodan) O. Schwarz \& Klink; pharmacognostic research; coumarins

\begin{abstract}
The article presents the data of the pharmacognostic research of the plant raw material from the overground parts of Medicago falcata L. subsp. romanica (Prodan) O. Schwarz \& Klink. The aim of our work was to determine the composition and the quantitative content of the components from the true coumarins class revealing the anticoagulation effect. The plant raw material was collected in the period of active vegetation. It was dried in a draught at the temperatures up to $40^{\circ} \mathrm{C}$. For the first time gas-liquid chromatography with mass spectrometric detection of the raw material extract has been performed. The components have been identified by the library of mass spectra NIST 05 and WILEY 2007 together with the programmes for identifying AMDIS and NIST. The internal standard method has been used for quantitative calculations. The data obtained have shown the presence of 66 compounds, and 38 of them have been identified and quantitatively characterized. The extract from the raw material of Medicago falcata L. subsp. romanica (Prodan) O.Schwarz \& Klink contains a number of biologically active substances in the native form - fatty acid and primary products of biosynthesis. Dihydrocoumarin and coumarin in the corresponding amounts have been identified from compounds of the true coumarin class in the overground parts of alfalfa (M. falcata $L$. subsp. romanica).
\end{abstract}

Medicago L. genus has 100 types of the world flora, 24 of them are wide spread on the territory of Ukraine. These plants were distributed from the natural habitat in South West Asia to many countries due to the armies of conquerors. Persians brought them to Greece in 480 B.C. as a feed for horses; Saracens - to Spain in the 8-th century. Alfalfa came to Mexico and South America with Spaniards, and from there to Texas and California in the 19-th century. Now alfalfa is planted all over the world $[1,3,8]$.

The places of its wide distribution are Europe, Caucasus, Middle Asia, Siberia, the south of Far East, Mongolia, China, the Korean peninsula, Himalayas, North America. Plants prefer steppe, forest zones on dry meadows, open slopes, in steppes, on the forest skirts, banks of the rivers, in crops $[1,2,10]$.

Medicago falcataL. subsp. romanica (Prodan) $\mathrm{O}$. Schwarz \& Klink is a perennial plant with straight standing, ascended or outstretched, branchy stems, which are downy-appressed, almost naked beneath. Leaves in a number of 3 are ranging from obovate to linear and toothed in the upper side; they are downy-naked or scattered on to pand downy-appressed from below. Flowers are yellow, in rather heavy clusters. The calyx is appressed-pilosed, serrations are linear-sabulate. The flag is elliptic, rounded on the top. Beans are flatly compressed, falcate-bent or straight, more or less downy, sometimes almost naked, polyspermous [4, 9].

Alfalfa is a well known agricultural plant. Some of its sorts are grown as vegetables and used in food, for example as salads. The green mass of alfalfa is a good feed for cattle and "green fertilizer", its flowers are remarkable honey plants $[6,7,8,10]$.

In the German ethnoscience the aqueous infusion of alfalfa is used in diabetes mellitus and dysfunctions of the thyroid $[5,11]$. It has a diuretic, antibacterial, general tonic action, assists renewal of the cartilaginous tissue of joints of the backbone $[9,10]$.

It is necessary to underline that there is no profound pharmacognostic analysis of plants - representatives of this Ukrainian flora type concerning the content of many biologically active substances, their accumulation, interaction with each other and with the environment.

The aim of this work is the pharmacognostic study of the composition and the quantitative content of free coumarins in the overground parts of the raw material of the representative of Medicago L. genus - Medicago falcate L. subsp. romanica (Prodan) O. Schwarz \& Klink.

\section{Materials and Methods}

The plant material (grass) was collected in the period of active flowering (May - June) in the suburb of Zaporizhzhya (the urban-type settlement Primorske). It was dried in a draught under the cover.

The research was conducted with the help of an Agilent Technologies 6890 chromatograph with a massspectrometer detector. The carrier gas was helium. The capillary chromatographic column with the internal diameter of $0.25 \mathrm{~mm}$ and the length of $30 \mathrm{~m}$ was used. To identify the components the library of mass spectra NIST 05 and WILEY 2007 together with the programmes for identifying AMDIS and NIST were used. 
Table

The component composition of the raw material of Medicago falcate L. subsp. romanica (Prodan) O. Schwarz \& Klink. collected in the urban-type settlement Primorske, Zaporizhzhya region (May-June) 2010-2013

\begin{tabular}{|c|l|c|c|l|c|}
\hline No. & \multicolumn{1}{|c|}{ Component } & Amount (mg \%) & No. & \multicolumn{1}{c|}{ Component } & Amount (\%) \\
\hline 1 & Hexanoic acid & 0.18 & 20 & $\begin{array}{l}\text { Loliolide [5, 6, 7, 7 a tetrahydro-6-oxy- } \\
\text { 4,4,7a trimethyl 2 (4H) benzofuranon] }\end{array}$ & 0.28 \\
\hline 2 & Benzylalcohol & 0.05 & 21 & Phytol & 3.74 \\
\hline 3 & Nonanal & 0.06 & 22 & Oleinic acid & 0.15 \\
\hline 4 & 2 phenoxyethanol (admixture) & 0.34 & 23 & Stearinic acid & 0.17 \\
\hline 5 & Tetradecane & 0.19 & 24 & Linolic acid & 2.23 \\
\hline 6 & Imidol 2,5 dione & 0.28 & 25 & Linolenic acid & 1.16 \\
\hline 7 & Pentadecane & 0.15 & 26 & Pentacosane & 0.35 \\
\hline 8 & Dihydrocoumarin & 2.17 & 27 & Heptacosane & 0.89 \\
\hline 9 & Dodecanoic acid & 0.04 & 28 & Phthalate & 0.34 \\
\hline 10 & Isopropyl laurate (admixture) & 0.05 & 29 & Octacosane & 0.26 \\
\hline 11 & Coumarin & 17.77 & 30 & Nonacosane & 7.53 \\
\hline 12 & Dihydroactinidilide & 0.40 & 31 & Eicosanol & 20.37 \\
\hline 13 & Octadecane & 0.10 & 32 & Hentriacontane & 1.82 \\
\hline 14 & Cis-neophytadiene & 3.04 & 33 & Campesterol & 0.51 \\
\hline 15 & Cis-, trans-neophytadiene & 0.48 & 34 & Stigmasterol & 1.04 \\
\hline 16 & Trans-neophytadiene & 0.78 & 35 & Y-sitosterol & 4.17 \\
\hline 17 & Hexahydrofarnesylacetone & 0.62 & 36 & $\beta$-amyrin & 0.19 \\
\hline 18 & Pentadecanoic acid & 0.26 & 37 & Lupeol & 0.27 \\
\hline 19 & Palmitic acid & 3.37 & 38 & a-amyrin & 0.21 \\
\hline
\end{tabular}

For quantitative calculations the method of the internal standard was used.

The content of the components was calculated by the formula:

$$
\mathrm{C}=\mathrm{K}_{1} \cdot \mathrm{K}_{2} \text {, }
$$

where: $\mathrm{K}_{1}=\mathrm{S}_{1} / \mathrm{S}_{2}\left(\mathrm{~S}_{1}\right.$ is the peak area of the substance investigated; $\mathrm{S}_{2}$ is the peak area of the standard); $\mathrm{K}_{2}=50 / \mathrm{M}$ (50 is the mass of the internal standard (mcg) introduced to the sample; $m$ is the weight of the sample (g)).

Abundance

\section{Results and Discussion}

The data obtained for free coumarins are given in Table.

While conducting gas-liquid chromatography (Fig.) 66 compounds have been found. Among them 38 compounds have been identified.

It should be noted that a rather great number of components belonging to the class of fatty acids (palmitic, linoleic, linolenic acids) has been found: 5.01\%; 3.32\%; $1.72 \%$, respectively.

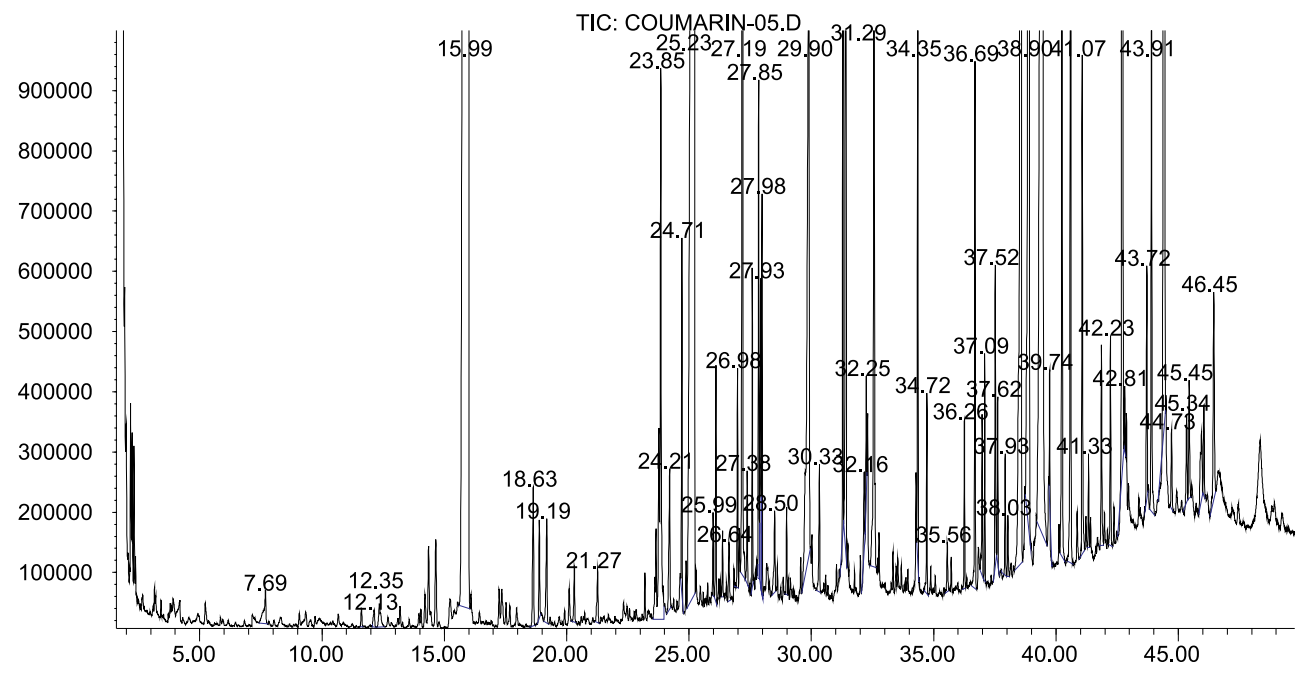


When conducting chromatography in the raw material of medick (Medicago falcata) biologically active products of primary biosynthesis (cis-neophytadiene, trans-neophytadiene, nonacosane, eicosanol, hentriacontane, stigmasterol, $\gamma$ sitosterol) have been identified.

Two compounds - dihydrocoumarin (2.17\%) and coumarin $(17.77 \%)$ have been identified from the class of true coumarins in the overground parts of alfalfa $(M$. falcata L. subsp. romanica).

CONCLUSIONS

1. For the first time gas-liquid chromatography with mass spectrometric detection of the raw material of $\mathrm{Me}$ - dicago falcata L. subsp. romanica (Prodan) O. Schwarz $\&$ Klink has been performed.

2. According to the data of gas-liquid chromatography 66 compounds have been found, and 38 of them have been identified.

3. The raw material of Medicago falcata L. subsp. romanica (Prodan) O.Schwarz \& Klink contains a number of biologically active substances in the native form - fatty acid and a number of products of primary biosynthesis.

4. Dihydrocoumarin and coumarin have been identified from compounds of the true coumarin class in the overground parts of alfalfa (M. falcata L. subsp. romanica).

\title{
REFERENCES
}

1. Дідух Я.П., Бурда Р.І., Зиман С.М. та ін. Екофлора Украӥни. - К.: Фітосоціочентр, 2004. - T. 2. - 480 с.

2. Канівецьь В.І., Канівец̧ь С.В. // Грунтознавство. - 2008. - T. 9, №1-2. - С. 48-52.

3. Новоселова Л.В., Росков Ю.Р., Качкина А.Б. // Вестник Пермского университета. Серия Биол. - 2004. Bbin. 2. - C. 64-71.

4. Шапаренко I. // Вісник Львівського університету. Серія Біол. - 2012. - Вип. 58. - C. 97-106.

5. Cieśla Ł., KowalskaI., Oleszek W. et al. // Phytochemical Analysis. - 2013. - Vol. 24, №1. - P. 47-52.

6. Ebrahimzadeh M.A., Pourmorad F., Bekhradnia A.R. // African J. Biotechnol. - 2008. - Vol. 7, №18. P. 3188-3192.

7. Kancheva V.D., Boranova P.V., Nechev J.T. et al. // Biochimie. - 2010. - Vol. 92. - P. 1138-1146.

8. Kowalska I., Stochmal A., Kapusta I. et al. // J. Agric. Food Chem. - 2007. - Vol. 55. - P. $2645-2652$.

9. Mirzaei1 A., Abbasi M., Sepehri S. et al. // Life Sci. J. - 2013. - Vol. 10, №11. - P. 27-31.

10. Olech M., Komsta E., Nowak R. et al. // Food Chem. - 2012. - Vol. 132. - P. 549-553.

11. Stochmal A., Kowalska I., Janda B. et al. // Phytochemistry. - 2009. - Vol. 70. - P. 1272-1276.

\author{
ВИВЧЕННЯ ВІЛЬНИХ КУМАРИНІВ У РОСЛИННІЙ СИРОВИНІ MЕDICAGО FALCATA L. \\ SUBSP. ROMANICA (PRODAN) O. SCHWARZ \& KLINK. \\ О.В.Гречана \\ Ключові слова: Medicago falcata L. subsp. romanica (Prodan) O. Schwarz \& Klink.; \\ фармакогностичне дослідження; кумарини
}

У роботі наведені дані фрармакогностичного вивчення рослинної сировини надземної частини Medicago falcata L. subsp. romanica (Prodan) O. Schwarz \& Klink. Meтою роботи вважали визначення та кількісну характеристику компонентів з класу істинних кумаринів, які виявляли антикоагуляційну дію. Заготовляли рослинну сировину в період масової вегетації. Висушували на протязі при температурі до $40^{\circ} \mathrm{C}$. Вперше було проведено газо-рідинне хроматографрування з мас-спектрометричним детектуванням екстракту з сировини. Компоненти ідентифікували за допомогою бібліотеки мас-спектрів NIST 05 i WILEY 2007 спільно з програмами для ідентифрікації AMDIS і NIST. Для кількісних розрахунків використовували метод внутрішнього стандарту. Отримані дані свідчили про наявність 66 сполук, з яких ідентифіковано і кількісно охарактеризовано 38 компонентів. При ідентифікації екстракт із сировини Medicago falcata L. subsp. romanica (Prodan) O. Schwarz \& Klink. в нативному вигляді містив ряд біологічно активних речовин - жирні кислоти і продукти первинного біосинтезу. 3 класу істинних кумаринів у заготовлених надземних частинах люцерни посівної (син. румунської) було ідентифіковано дигідрокумарин і кумарин у відповідних кількостях.

\section{ИЗУЧЕНИЕ СВОБОДНЫХ КУМАРИНОВ В РАСТИТЕЛЬНОМ СЫРЬЕ MЕDICAGО FALCATA L. SUBSP. ROMANICA (PRODAN) O. SCHWARZ \& KLINK. Е.В.Гречаная}

Ключевые слова: Medicago falcata L. subsp. romanica (Prodan) O. Schwarz \& Klink.; фрармакогностическое исследование; кумарины В работе поданы данные фрармакогностического изучения растительного сырья надземной части Medicago falcata L. subsp. romanica (Prodan) O. Schwarz \& Klink. Целью работы считали определение и количественную характеристику компонентов из класса истинных кумаринов, которые проявляют антикоагуляционное действие. Заготавливали растительное сырье в период массовой вегетации. Высушивали на сквозняке при температуре до $40^{\circ} \mathrm{C}$. Впервые было проведено газо-жидкостное хроматографирование с масс-спектрометрическим де- 
тектированием экстракта из сырья. Компоненты идентифицировали с помощью библиотеки масс-спектров NIST 05 и WILEY 2007 совместно с программами для идентификации AMDIS и NIST. Для количественных расчетов использовали метод внутреннего стандарта. Полученные данные свидетельствовали о наличии 66 соединений, из которых идентифицировано и количественно охарактеризовано 38 компонентов. При идентификации экстракт из сырья Medicago falcata L. subsp. romanica (Prodan) O. Schwarz \& Klink. в нативном виде содержал ряд биологически активных веществ - жирные кислоты и продукты первичного биосинтеза. Из класса истинных кумаринов в заготовленных надземных частях люцерны посевной (син. румынской) были идентифицированы дигидрокумарин и кумарин в соответствующих количествах. 